Vol. 4, No. 3, 2019

\title{
FRESHWATER ECOSYSTEM MACROPHYTES AND MICROPHYTES: DEVELOPMENT, ENVIRONMENTAL PROBLEMS, USAGE AS RAW MATERIAL. REVIEW
}

\author{
Khrystyna Soloviy, Myroslav Malovanyy \\ Lviv Polytechnic National University, \\ Institute of Sustainable Development, \\ Department of Ecology and Sustainable, Environmental Management, \\ 12, S. Bandery Str., Lviv, 79013, Ukraine \\ christina.gf@gmail.com, myroslav.mal@gmail.com
}

https://doi.org/10.23939/ep2019.03.115

Received: 19.06.2019

(C) Soloviy K., Malovanyy M., 2019

\begin{abstract}
Classification of macrophytes and microphytes in the system of hydrobionts is presented, individual characteristics of each macrophyte and microphyte type according to the given classification are presented, environmental problems concerning uncontrolled development of macrophytes and microphytes in water media are considered and several biotechnologies of application of their sustainable development are characterized.
\end{abstract}

Key words: macrophytes, microphytes, uncontrolled development, biomass, biotechnologies

\section{Introduction}

Macrophytes and microphytes play an important role in water and wetland ecosystems. [28] Presence or absence of sertain macrophyte and microphyte species can depict sertain environmental state of local environment. A lot of representatives are used in bioindication which is an important process for revealing pollution level of the studied environment and for strategic water purification planning. These hydrobionts are interdependent and complementary. Besides bioindication, a lot of representatives are a nutrition source for many invertebrates. In the system of environmental balanced management there are also many biotechnologies using macrophyte and micrpophyte species as a source for target production.
The purpose of the article is to get acquainted with classification of macrophytes and microphytes, study risks and dangers that they may cause for the environment, conduct critical analysis of biotechnologies with their application.

\section{Classification of macrophytes}

Macrophytes, hydrobionts or aquatic plants are representatives of flora that grow in the water medium or close to water. Aquatic plants are producers of water ecosystem. They regulate penetration of sunlight and provide survival of water ecosystem. Despite the fact that these plants originated in water, the majority of acquatic plants except algae (that will be considered as microphytes) originate from their mesophyte relatives.

Division of macrophytes is based on sertain factors.

Depending on the connection with water and air [48] macrophytes can be divided into:

1. free floating;

2. floating but rooted;

3. submerged (floating and rooted);

4. amphibian plants.

Free floating macrophytes float freely on the surface and have no roots in the mud. Freely floating hydrobionts shape a dense population, covering water surface. Such population prevents development of submerged aquatic plants and phitoplancton by blocking 
penetration of light. These hydrophytes can be big, shaping a column in a rosette and have very well developed roots, grow submerged (Eichhornia crassipes) and small. Small freely floating macrophytes have simplier bodies, with talon shape and reduced roots (Lemna gibba, L. minima, Azolla filiculoides). Many of them are predatory species that impede the use of water body and accelerate evaporation, hence reducing water reserves (Eichhornia crassipes, Limnobium laevigatum) [54] An average representative of freely floating macrophytes is presented in Fig. 1.

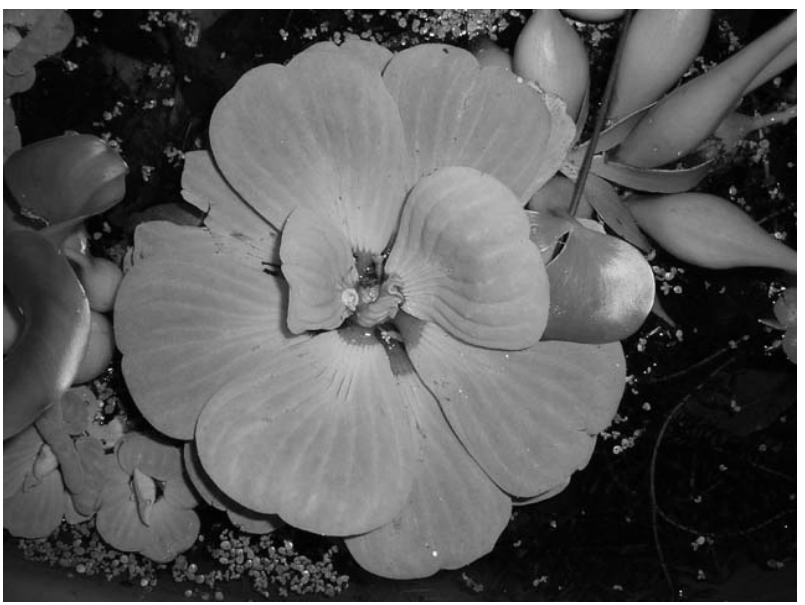

Fig. 1. Pistia stratiotes. Superclass - Magnoliophyta; order - Alismatales; family - Araceae

(https://www.eddmaps.org/)

Floating but rooted hydrophytes appear in pounds, rivers and lakes. Life and blooming of these bionts take place on the water surface. Such group of macrophytes includes Nelumbium speciosum (lotus), Victoria regia (water lily), Ceratopteris thalictroides (hydrophil fern of Parkariaceae family) etc. [81]. A representative of floating but rooted macrophytes is shown in Fig. 2.

Some parts of floating macrophytes are in contact with water when simultaneously other parts float on the water or above its surface. These plants consume $\mathrm{CO}_{2}$ and oxygen from the water, and partly from the air. These hydrobionts can develop heterophilicity. Submerged leaves of floating aquatic plants are thin, ribbons are shaped completely or dissected, and those that float on the water surface are well extended and unbroken. The surface of the plant body is covered with a thin wax film that protects the plant tissue from injuries caused by water and also prevents stomata clogging. Stomata are limited to the upper part of the floating leaves. Palisade cells are less developed with spongeous tissue. Roots of floating macrophytes are well developed, filament-vessel system is considerably reduced, aerenchyme develops with excess and air chambers are rather large. In some representatives of floating macrophytes the root is absent while in the others it can be fully developed. Root hairs of free floating hydrophytes lay in right angles to the axis of the main root. In some free floating macrophytes roots can be modified into trails as in Jussiaca. Their roots have weak differentiation of inner tissues. Roots function as an absorbing or anchor organ [27].

Submered floating microphytes grow under the water surface and are not in contact with the atmosphere. Typical representatives of submerged floating macrophytes are Ceratophyllum, Utricularia [14]. A typical representative of submerged floating macrophytes is shown in Fig. 3.

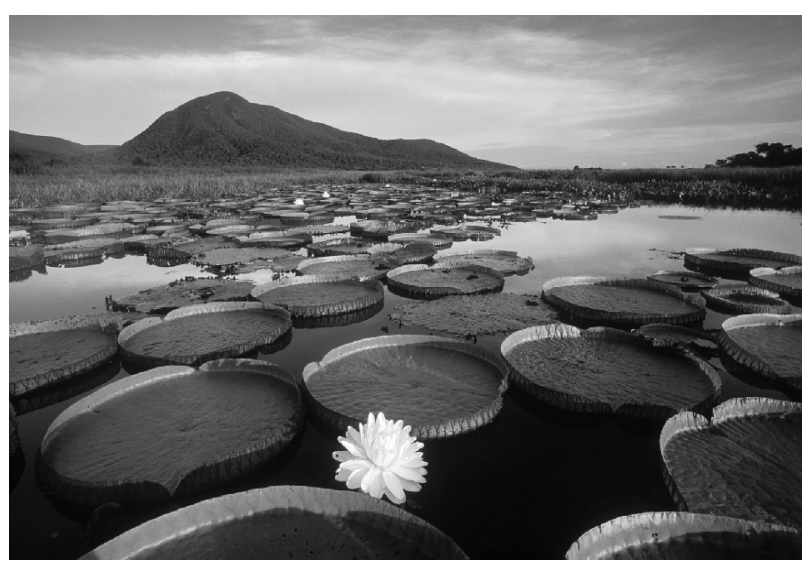

Fig. 2. Victoria regia (Victoria amazonica). Superclass Magnoliophyta; family - Nymphaeaceae; genus - Victoria (http://www.guiasybaquianos.com/en/)

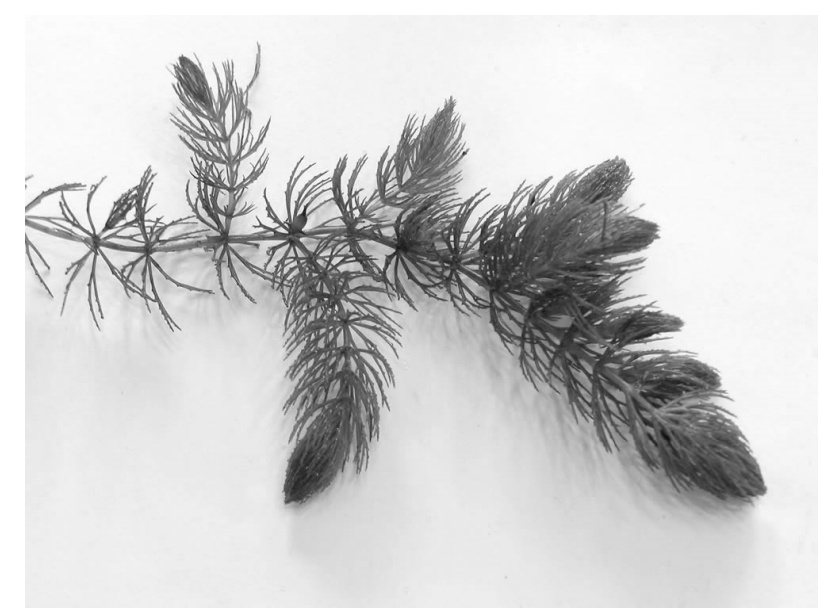

Fig. 3. Ceratophyllum demersum. Order - Ceratophyllales; family - Ceratophyllaceae; genus - Ceratophyllum (https://www.plantsrescue.com/ceratophyllum-demersum/) 
Submerged rooted macrophytes are rooted in mud. This type of macrophytes includes Hydrilla, Vallisneria, Potamogeton. [14] One of the representatives of submerged rooted macrophytes is shown in Fig. 4.

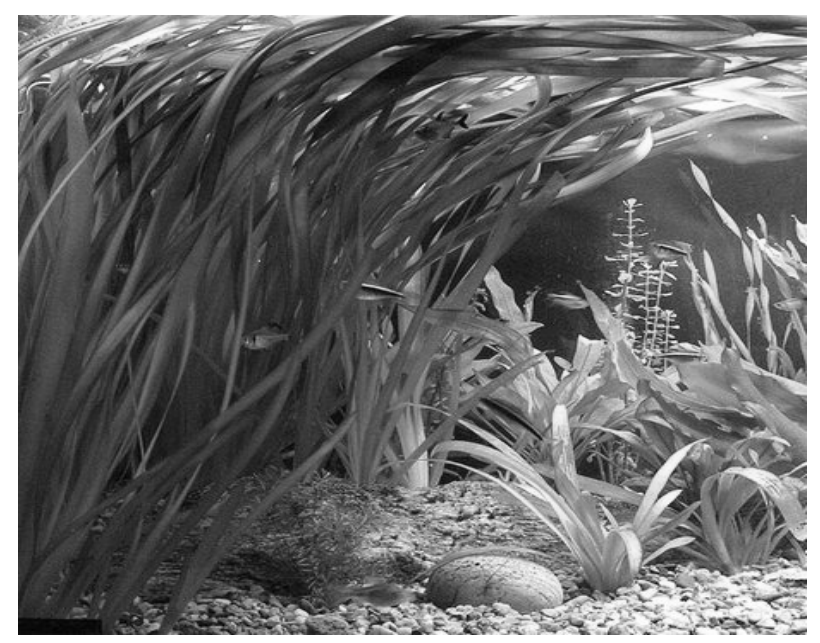

Fig. 4. Vallisneria gigantea. Order - Alismatales; family - Hydrocharitaceae; genus - Vallisneria (https://www.amazon.com/)

The entire surface of the plant body in macrophytes is in direct contact with water. Leaves of such plants consume $\mathrm{CO}_{2}$ and oxygen from the water. Heterophylicity is not spread. Leaves of such macrophytes are considerably reduced in size. Cuticle, suberin and epidermis cover are absolutely undeveloped. Stomata in such hydrophyte plants are absent or present in the reduced state. Mesophyl tissue is in the shape of aerenchyma that blocks large air chambers. Palisade and spongeous parenchyma are not well differentiated. Stems in such submerged macrophytes are very thin and considerably reduced. They move on substrate with rhozomes or sprouts. Their stems have poorly developed vascular bounds. Aerenchyma is very well developed and air chambers are separated by cross partitions or diaphragms. Roots in submerged macrophytes are considerably reduced, without branches and rhizome hairs. They act as anchor organs. Root system has poor inner organization [27].

Amphibian plants grow in shallow waters. Their roots, stems and leaves are rooted in the water. But some blooming sprouts blossom above the water surface.These plants are adapted to the water and terrestrial life conditions. Air parts of these hydrobionts have mesophytic characteristics, when submerged parts develop completely hydrophytic characteristics. Typical representatives of amphibian plants are Limnophylla heterophylla, Typha, Sagittaria. A typical amphibian plant is shown in Fig. 5.

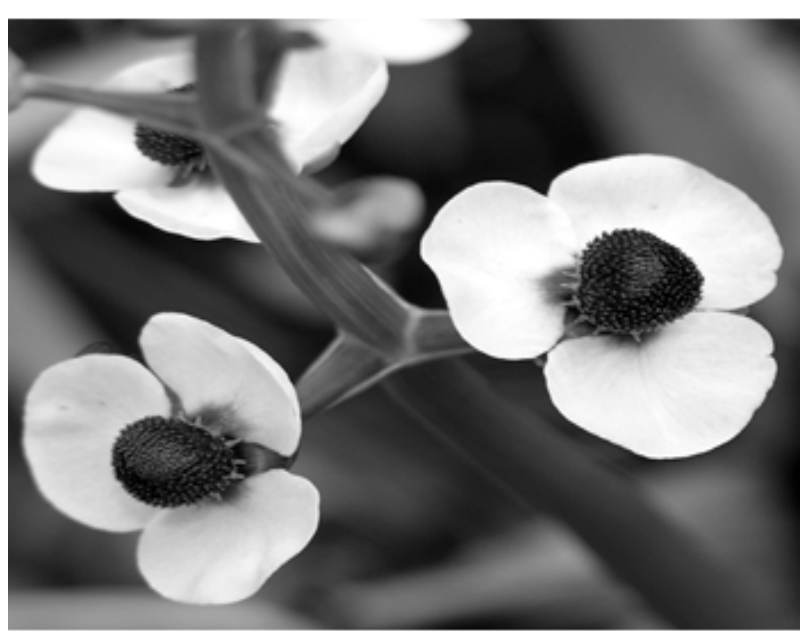

Fig. 5. Sagittaria sagittifolia. Order - Alismatales; family - Alismataceae; genus - Sagittaria (https://www.ebay.co.uk/)

In amphibian plants spme parts of their body grow in the water when others grow above the water surface or even on the land. The leaves in these hydrophytes absorb $\mathrm{CO}_{2}$ and oxygen from the air because they are well opened and the gaseous exchange can take place very easily through stomata. Heterophylicity in amphibian plants is quite common. The leaves are large, unbroken and both big and small leaves are located above the water surface. Cuticle develops in the airial part of the plant. Stomata are limited to the upper and lower parts of aerial leaves. Mesophyll has clear differentiation into spongeous and palisade tissues. Spongeous parenchyma is well developed with high aerial passages of the diaphragms. The stem is excessively developed, but in some representatives it can be reduced to the rhizome. This indicates clear differentiation of epidermis, cortex and vessel zones. Cortex in some cases is differentiated into separated zones. The outer root is aerenchymatous and it blocks large aerial spaces. The inner root and core can be shaped into thick wall cells. The roots of the amphibian plants are well developed. They show good differentiation of all inner tissues. Root hairs develop on epidermis.

Macrophytes have several ecological adaptations that are divided into morphological, anatomical and physiological factors. More information about adaptation peculiarities of macrophytes is shown in Table 1. 
Ecological adaptations of macrophytes [4]

\begin{tabular}{|c|c|c|c|c|}
\hline \multicolumn{2}{|r|}{ Morphological adaptations } & \multicolumn{2}{|r|}{ Anatomical adaptations } & Physiological adaptations \\
\hline & $\begin{array}{l}\text { Poorly developed, reduced or } \\
\text { absent }\end{array}$ & \multirow{5}{*}{ 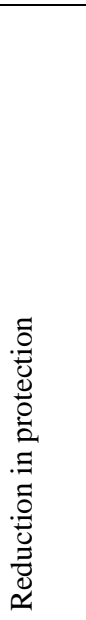 } & $\begin{array}{l}\text { Cuticle is completely absent in } \\
\text { submerged parts }\end{array}$ & $\begin{array}{l}\text { Low osmotic concentration of } \\
\text { cellular juice }\end{array}$ \\
\hline & $\begin{array}{l}\text { Do not require absorbing } \\
\text { water or nutrients }\end{array}$ & & $\begin{array}{l}\text { In airial parts cuticle can be present as } \\
\text { a thin layer }\end{array}$ & $\begin{array}{l}\text { Osmotic concentration is equal or } \\
\text { slightly higher than that which is } \\
\text { surrounding the water }\end{array}$ \\
\hline & $\begin{array}{l}\text { The entire plant surface can } \\
\text { absorb water and minerals }\end{array}$ & & Epidermis is not a protective layer & $\begin{array}{l}\text { Prevents undesirable penetration } \\
\text { of water into the cell }\end{array}$ \\
\hline & $\begin{array}{l}\text { Root capsules are usually } \\
\text { absent }\end{array}$ & & Epidermal cells contain chloroplasts & $\begin{array}{l}\text { Water is absorbed by the entire } \\
\text { surface of the plant }\end{array}$ \\
\hline$\underset{\mathscr{0}}{\stackrel{\infty}{0}}$ & $\begin{array}{l}\text { Root surface is often supplied } \\
\text { with root pockets or root } \\
\text { films }\end{array}$ & & $\begin{array}{l}\text { Epidermal cells can absorb water and } \\
\text { nutrients }\end{array}$ & $\begin{array}{l}\text { Nutrients are absorbed by the } \\
\text { entire surface of the plant }\end{array}$ \\
\hline \multirow[b]{2}{*}{$\frac{\mathscr{E}}{\tilde{E}}$} & $\begin{array}{l}\text { The stem is very delicate and } \\
\text { usually green }\end{array}$ & \multirow{6}{*}{ 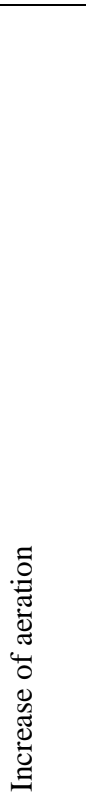 } & $\begin{array}{l}\text { Stomata is completely absent in } \\
\text { submerged parts }\end{array}$ & $\begin{array}{l}\text { Stems and leaves can } \\
\text { photosynthesize }\end{array}$ \\
\hline & $\begin{array}{l}\text { In the majority of } \\
\text { representatives the stem is } \\
\text { modified into a rhizome or a } \\
\text { sprout }\end{array}$ & & $\begin{array}{l}\text { Remnant stomata are sometimes } \\
\text { present }\end{array}$ & $\begin{array}{l}\text { Oxygen obtained r by } \\
\text { photosynthesis is kept in aerial } \\
\text { spaces }\end{array}$ \\
\hline \multirow[b]{8}{*}{ 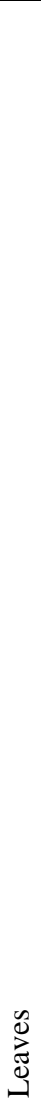 } & $\begin{array}{l}\text { In free floating macrophytes } \\
\text { leaves are long, circular, } \\
\text { green, thin and smooth }\end{array}$ & & $\begin{array}{l}\text { Gaseous exchange takes place through } \\
\text { the cellular wall }\end{array}$ & $\begin{array}{l}\text { Such oxygen is utilized when } \\
\text { necessary }\end{array}$ \\
\hline & $\begin{array}{l}\text { The upper part is exposed to } \\
\text { the air, while the lower part } \\
\text { touches the water }\end{array}$ & & $\begin{array}{l}\text { Stomata in floating plants are limited } \\
\text { to upper leaf epidermis }\end{array}$ & $\begin{array}{l}\text { Evaporation is absent in } \\
\text { submerged plants }\end{array}$ \\
\hline & $\begin{array}{l}\text { The lotus petiole leaf shows } \\
\text { uncertain growth and hence } \\
\text { holds leaves floating in the } \\
\text { water }\end{array}$ & & $\begin{array}{l}\text { Aerenchyma is well developed in } \\
\text { submerged plants }\end{array}$ & $\begin{array}{l}\text { Emerging and floating plants have } \\
\text { excessive evaporation }\end{array}$ \\
\hline & $\begin{array}{l}\text { Some representatives are } \\
\text { heterophylic }\end{array}$ & & $\begin{array}{l}\text { Aerenchyma aerial cameras are filled } \\
\text { with respiratory gases and moisture }\end{array}$ & Slime cells create a lot of slime \\
\hline & $\begin{array}{l}\text { In heterophylic forms the } \\
\text { submerged leaves are linear, } \\
\text { ribbon or very dissected, } \\
\text { while the floating or aerial } \\
\text { leaves have a circular form }\end{array}$ & \multirow{4}{*}{ 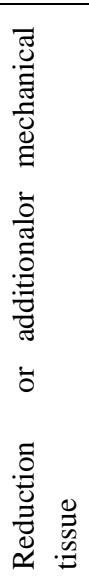 } & $\begin{array}{l}\text { Mechanical tissues are absent or } \\
\text { poorly developed }\end{array}$ & $\begin{array}{l}\text { Slime prevents plants from } \\
\text { decomposition in the water }\end{array}$ \\
\hline & $\begin{array}{l}\text { The leaves of free floating } \\
\text { hydrophytes have a smooth } \\
\text { wax surface }\end{array}$ & & $\begin{array}{l}\text { Thick strengthened sclerenchyma cells } \\
\text { are completely absent }\end{array}$ & $\begin{array}{l}\text { Vegetative reproduction is the } \\
\text { most common type of } \\
\text { reproduction }\end{array}$ \\
\hline & $\begin{array}{l}\text { Prevent from water pollution } \\
\text { during raining seasons }\end{array}$ & & $\begin{array}{l}\text { Nymphaea has a special type of star } \\
\text { lignification cells (astrosclereids) } \\
\text { which provides mechanical support }\end{array}$ & $\begin{array}{l}\text { Allogamy and scattering of fruit } \\
\text { take place with the help of water }\end{array}$ \\
\hline & $\begin{array}{l}\text { Wax surface protects leaves } \\
\text { from chemical or physical } \\
\text { injuries }\end{array}$ & & $\begin{array}{l}\text { The main function: the root is an } \\
\text { anchor (not absorbing nutrients and } \\
\text { water) }\end{array}$ & \\
\hline
\end{tabular}

C. Ramirez G. and M. Alvarez have divided the types according to macrophyte groups. The biggest rate has the group of glycophyte helophytes. More detailed division is shown in Table 2. 
Table 2

\section{Division of types according to the macrophyte groups [18]}

\begin{tabular}{|l|c|c|}
\hline Macrophyte groups & Species & Percent \\
\hline $\begin{array}{l}\text { Deeply sybmerged } \\
\text { hydrophytes }\end{array}$ & 22 & 9.7 \\
\hline $\begin{array}{l}\text { Free submerged } \\
\text { hydrophytes }\end{array}$ & 4 & 1.8 \\
\hline $\begin{array}{l}\text { Free floating } \\
\text { hydrophytes }\end{array}$ & 11 & 2.6 \\
\hline $\begin{array}{l}\text { Floating } \\
\text { hydrophytes }\end{array}$ & 112 & 4.8 \\
\hline $\begin{array}{l}\text { Glycophylic } \\
\text { helophytes }\end{array}$ & 22 & 9.4 \\
\hline $\begin{array}{l}\text { Halophilic } \\
\text { helophytes }\end{array}$ & 32 & 14.1 \\
\hline $\begin{array}{l}\text { Herbaceous } \\
\text { amphibian } \\
\text { helophytes }\end{array}$ & 18 & 7.9 \\
\hline Forest helophytes & 227 & 100 \\
\hline Total & & 9.7 \\
\hline
\end{tabular}

\section{Microphytes}

In this article in the section on microphytes we will mainly concentrate our attention on microalgae.

Microalgae are unicellular microorganisms that have plant characteristics and usually grow in water medium; this is why these organisms refer to hydrobionts.

There is no definite classification of microalgae since they do not represent formal taxonomic group of organisms but rather heterogeneous collection of phylums or divisions with representatives in several kingdoms. The divisions differ from each other by the combination of characteristics, including photosynthetic pigments, starch-like reverse products, cellular cover and other aspects of cellular organization (e.g., Graham et al., 2008; Lee, 2008) . Cyanobacteria, red algae, green algae, euglenozoa, eustigmatophyta, raphidophyta, xanthophyceae, chrysophyceae, haptophyta, synurophyceae, diatoms, dinoflagellates, cryptophyta, brown algae can be attributed to freshwater microalgae. We will analyze some of them.

Euglenozoa live both in freshwater and marine water. Some euglenozoa are authotrophs, when some are heterotrophs. The most distinguished characteristic of these algae is prominent cellular wall. It is known as pellicula and is made from protein strips. Thanks to this pellicula a lot of species can bend and this enables modification of cell [9].

A representative of euglenozoa is shown in Fig. 6.

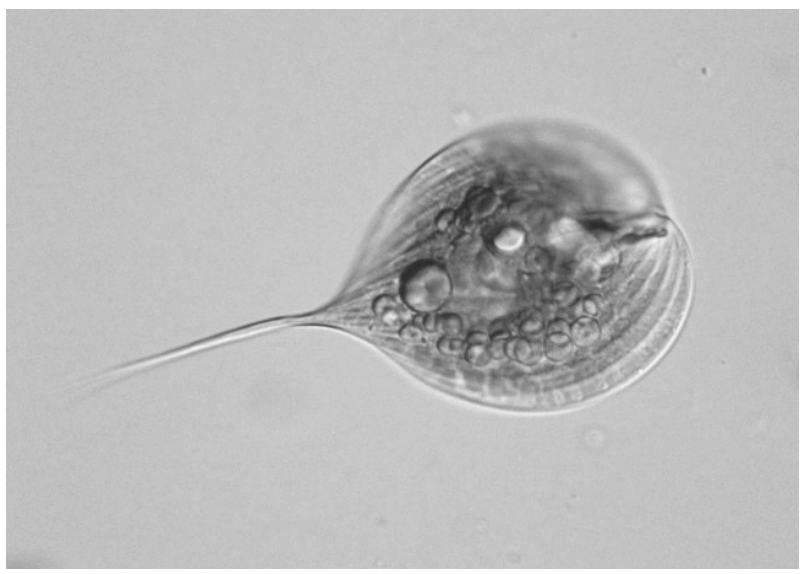

Fig. 6. Phacus longicauda. Class - Euglenoidea; order Euglenales; family - Euglenaceae (http://protist.i.hosei.ac.jp/ )

Yellow - green algae (xanthopytes) have more than 600 species. Representatives of this group are photosynthetic organisms that live mainly in freshwater, though some live in marine waters, humid soils and tree stems. This type is not very common and some species were discovered only once. Nevertheless they are dominant in some salty swamps [15].

In Fig. 7 a representative of yellow-green algae is shown.

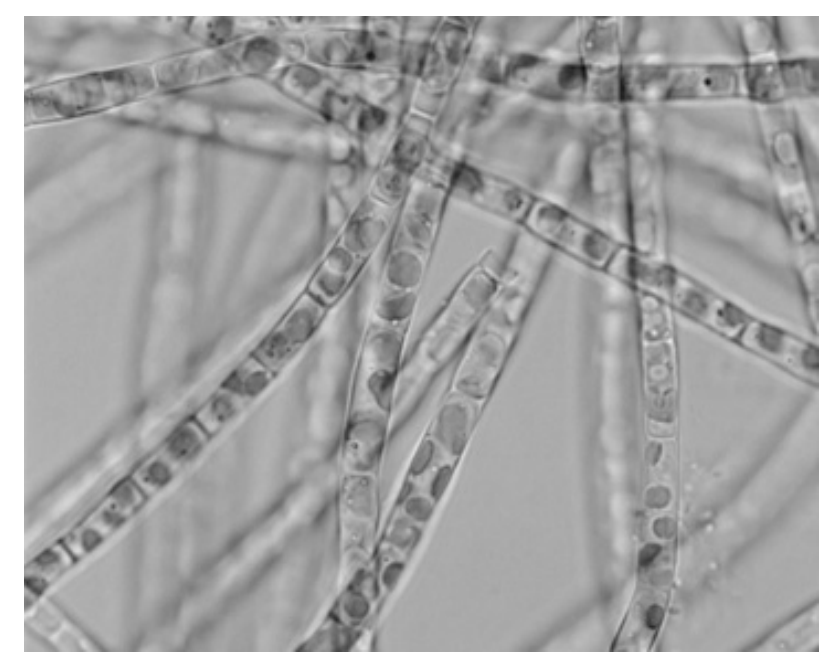

Fig. 7. Tribonema. Class - Xanthophyceae; order Tribonematales; family - Tribonemataceae (http://fmp.conncoll.edu/ )

There are more than 1800 species of brown algae. The most numerous and popular is kelp. Brown algae are often rooted in such immobile substrate as stone, shell or dock with structures that are called holdfasts, though species in genus Sargassum are free floating. A lot of species of brown algae have aerial bladders that help algae blades fload to ocean surface, which enables maximum absorbtion of sunlight [33]. 
In Fig. 8 a typical representative of brown algae is shown.

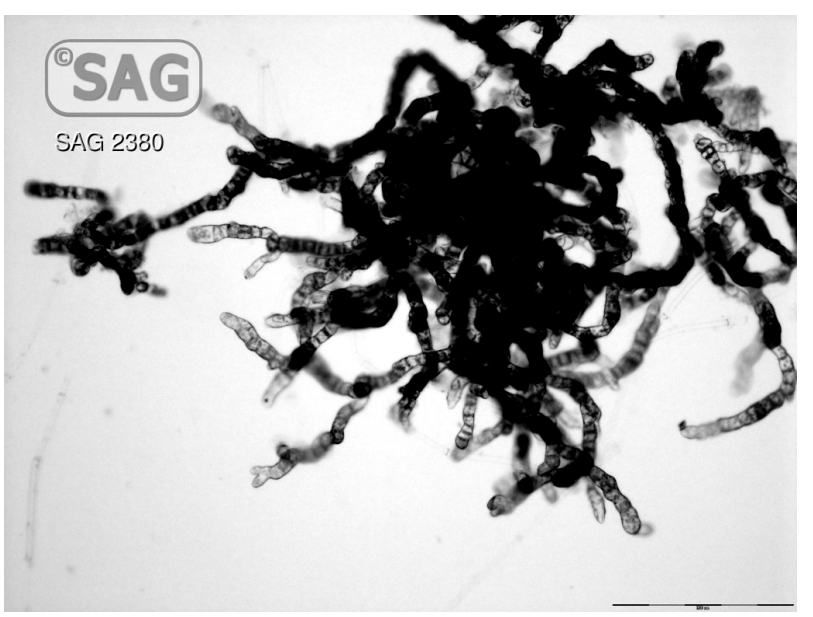

Fig. 8. Heribaudiella fluviatilis. Order - Ectocarpales; family - Phaeostrophiaceae; genus - Heribaudiella (https://sagdb.uni-goettingen.de/)

Green algae live in freshwater. These algae have cellular walls made from cellulose and are photosynthetic. Green algae also make up the most heterogenous group of photoautotrophic unicellulars that inhabit the biosphere and have a great variety of sizes, shapes and habits. As primary producers green algae are of great value for our planet in comparison with those that inhabit rainforests [20].

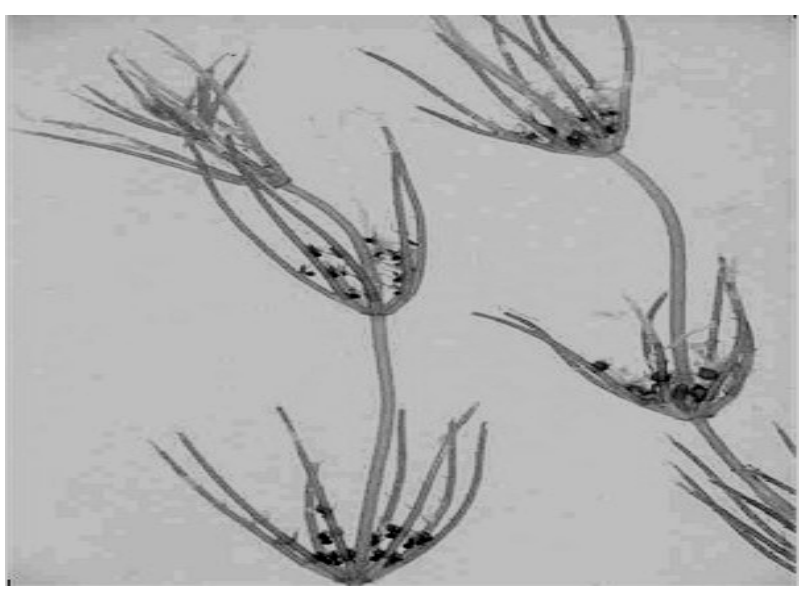

Fig. 9. Chara asp. Class - Charophyceae; order - Charales; family - Characeae (https://fortress.wa.gov/)

Dangers associated with uncontrolled growth of macrophytes and microphytes

A problem with excessive growth of microalgae in water (so-called "water blooming") is constantly growing and leads to acute consequences for both local aquatic biomes and for population that consumes water. For instance, analyzing EPA reports of 2018 , it is clear that the problem of water blooming is one of the key problems in the system of environmental problems [6]. Speaking about the types of algae that cause blooming of water, first of all it is blue - green algae (cyanobacteria) that can produce cyanotoxins that can harmfully affect human health and kill representatives of aquatic culture of local water and other animals. As for the detrimental effects on human organism, these are hepatitis (concerning liver), neurologic, dermatologic and other symptoms [10]. A human can be affected by such symptoms as a result of contact with water. This refers not only to swimming and consuming such water, but also consuming fish or shellfish from the infected water. Also inhaling toxins contained in the atmosphere in such location can lead to aforementioned consequences [16].

Apart from cyanobacteria, dinoflagellates and diatoms are among the microalgae that can cause water blooming, but they refer to marine waters.

In diatoms domoic, acid can cause shellfish amnesia intoxication in humans that consume shellfish or cancroids, and consequences might be anxiety, short memory loss, headache, and in worse cases - death [21].

Dinoflagellates produce toxins that can harmfully affect human health through consumption of sea foods or under direct conact with blooming waters. Toxins can cause serious diseases in humans. Such diseases are shellfish paralytic poisoning, diarrhea, shellfish neurotic poisoning, ciguatera fish poisoning [7].

Cyanobacteria can grow under very low concentration of nutrients and their capability to change their vertical position enables them to embrace optimum depth for their development [17].

Toxins that cyanbacteria can produce are microcystins, cylindrospermopsins, anatoxins - a, saxitoxins. These toxins can affect the human in the following way: liver damage, paralysis, neurotoxication, gastrointestinal lesions, dermatitis and respiratory system damage. In fauna it is first of all mortality of domestic, farm animals and mortality of fish. In the environment it is decoloration and foul odour. Economic consequences include loss of tourism attraction, drinking water pollution, demand for more expensive means of cleaning contaminated water or alternative water sources, taste problems in farm or wild fish (unsuitable for consumption) [10]. 


\section{Eutrophication problem}

Eutrophication problem means excessive growth of water plants or water blooming due to high concentrations of nutrients in freshwater ecosystems (rivers, basins, lakes). The main driving force of freshwater eutrophication process is contamination with such nutrition elements as phosphorus from agricultural fertilizers, sewage drains or urban storm drains. Beyond the accumulation of phosphorus there activates a processing mechanism that keeps the system blocked in eutrophication state even under consistently reduced supply of these components. Freshwater eutrophication problem can considerably affect such ecosystem services as fishery, recreation, esthetics and health [19].

The most visible effect of eutrophicaion process is formation of noxious and foul phytoplankton dense blooms that reduce water clarity and damage its quality. "Blooming" leads to reduction of light penetration, decrease in growth and death of plants in a coastal zone, and it also reduces the chance for successful hunting of predators that need light to catch a prey (Lehtiniemi et al. 2005). When algae that cause water blooming finally die, their microbal decomposition consistently reduces concentration of oxygen, creating hypoxic or anoxic "dead zones" that require oxygen for vital activity support [24].

\section{Problems of development of invasive macrophytes}

The problem of uncontrolled development of macrophyte representatives also has a detrimental affect on the ecosystem.

The most popular among invasive macrophytes is Eichhornia crassipes causing creation of dense layers on the water surface as a result of uncontrolled development. It is a great aquatic problem. Eichhornia crassipes or more commonly known as water hyacinth is regarded to be the biggest water plant in the world. Rapid growth and expansion of plants in new territories resulted from pecularities of its vegetative reproduction when one plant can develop consistent parasite poisoning. Moving easily with water stream or by other means, such as fish nets, boats, this plant seized channels, pounds, swamps and other freshwater bodies. The main problems that appear as a result of water hyacinth growth in dense layers are enormous water losses due to evaporation, which changes water balance of entire regions; obstruction to the flow of water, which increases sediment causing floods and soil erosion, obstruction to navigation and fishering and considerable decrease in catches and food sources for local population; significant changes in physical and chemical properties of water and the medium with invasive water bodies, with harmful effects on plants and anomals; reduction of electric plants activity, which is risky for country`s energy supply; serious threat to agricultural production, which leads to blocking of channels and dranage system. Economy of the countries suffering from such problem concerns many aspects. Eichhornia crassipes creates a serious environmental problem and affects human health indirectly since it can create microenvironment for development of different human diseases and is a centre for many hazardous reptiles [23].

\section{Biotechnologies with using macrophytes as raw} material

A representative of macrophytes Eichhornia crassipes appeared to be effective in biotechnological application, particularly concerning removal contaminants. Water salad is among the macrophytes which are effective in removing contaminants. Abdulrashid Muhammad Haidara et al. used in their studies Eichhornia crassipes in bioremediation of agricultural discharges. It was established that activity of this plant increased with the increase of weight and duration and such method of agricultural effluents purification appeared to be a great alternative in comparison with traditional methods. Advantages of such method were in its efficiency and small expenses; considerable amount of biodegradable mineral components was removed [1].

Dilek Demirezen Yilmaz et al. used in their studies Phragmites australis, Typha angustifolia, Potamogeton pectinatus, Ranunculus sphaerosphermus and Groenlandia densa for ferrum and magnesium bioindication in wetlands [35]. The studies have also established that duckweed and water hyacinth have purification properties for removal of organic contaminants. Over the last decades scientists have proven that such floating hydrobionts as Eichhornia crassipes, Pistia stratiotes, Hydrocotyle umbellata, Lemna minor, Alternanthera philoxeroides, Cleistocalyx operculatus have the best influence on purification of water damaged by eutrophication [28].

Dilek et al. have also conducted research using representatives of macrophytes and microphytes for purification of wastewater. They used Chlorella vulgaris, Limna spp, Eichhornia crassipes. As a result of the studies the scientists established that aforementioned 
hydrobionts are capable of reducing the quantity of contaminants to irrigation level. COD and BOD reduced (43\% and $42 \%$ ) owing to Limna spp, (28\% and $33 \%$ ) owing to Eichhornia crassipes and (33\% and $38 \%)$ owing to Chlorella vulgaris in 21 days. Limna spp appeared to be more effective in removal of such contaminants as nitrogen, phosphorus, potassium and other heavy metals from Eichhornia crassipes and Chlorella vulgaris and can be used as animal fodder. Limna spp hence appeared to be perspective in application for effluents purification from Eichhornia crassipes and Chlorella vulgaris.

Eichhornia crassipes can be used as a fertilizer. Bengali people and other Asian nations used this macrophyte species to fertilize their land. Application methods differed depending on the regions. Some used it as compost when other poured it as liquid manure on the ground; the rest used it as powder on the agricultural land. This hydrobiont is also suitable for raw materials at a biogas plant. From 1 ha of the harvested plants $70.000 \mathrm{~m}^{3}$ of gas can be produced, i.e. from $1 \mathrm{~kg}$ of dry plant matter 370 liters of gas is produced. In the southern part of South America Eichhornia crassipes was used for purification of sewage discharges. Many researches showed that this plant can absorb all types of organic and inorganic elements. This means that this hydrobiont can be used for wastewater purification, particularly for absorbing heavymetals and radioactive metals [32].

Jacques Slembrouck et al. conducted their studies in the field of using floating macrophytes for intensification of fishing process in tropical areas. For their studies the scientists used such floating macrophyte species as Eichhornia crassipes, Lemna minor, Azolla filiculoides, Salvinia molesta and Salvinia spp. Six parameters were set including productivity, nutrient value, unproductive cycle risk, impact on the water quality, taste qualities and simplicity of use. As a result of the studies it was established that Azolla filiculoides has the highest productivity, Lemna minor has the biggest rate among the nutrition value and taste qualities and Eichhornia crassipes showed the lowetst risk of unproductive cycles and positive effect on the water quality. After integrating the results with the help of multiparameter matrix it was established that Azolla filiculoides gives the best general result [30].

Macrophytes can be used for biofuel production. Monia Renzi et al. conducted their studies using Chaetomorpha linum, Ulva laetevirens, Valonia aegagrophyla, Gracilariopsis longissima, Ruppia cirrhosa for biodiesel production with the help of accelerated lipids extraction. During this research wet and dry tissues were extracted and the effect facilitated lipid renewal by pressure and the obtained micture was examined. The results have shown that better extraction takes place when polar/hydrophobic soluble mixture is used. Acceleration extraction method with the help of the dissolved substance considerably improves the general number of extracted lipids from macrophyte tissue even under the average value of dry matter of $2 \%$. [25]

William R. Brogan III et al. conducted their studies in the field of using representatives of macrophytes for reduction or direct and indirect insecticide action on freshwater mediums. The scientists used Elodea canadensis. As a result of the studies, macrophytes showed capability of reduction toxicity level of the water polluted by insecticides [3].

Brogan and Relyea [2] demonstrated that thanks to Elodea canadensis it was possible to reduce toxicity level 9 times in the water caused by insecticide malathion to cladocera daphnia manga in small jars. It was established that toxicity reduced with the increase in macrophyte number. When submerged macrophytes photosynthesize, they increase $\mathrm{pH}$ level thanks to absorbing $\mathrm{CO}_{2}$, which reduces concentration of carbonic acid and changes hydrocarbonate buffer system to more alkali hydrocarbonate and carbonate [34]. This higher level of $\mathrm{pH}$ facilitates faster malathion degradation through alkali hydrolysis [13].

Macrophytes can block growth of phytoplankton due to allelopathy [12] and competition for water nutritions [29].

Nele Stabenau et al. studied the use of macrophytes as a source of phosphorus fertilizer for organic farming with the help of anaerobic digestion method. The scientists used Elodea nuttallii since this hydrobiont can generate high biomass levels in the water with good supply of nutrients and the corresponding amount of phosphorus [31].

There are a lot of ways for application of microphytes with the help of biotechnologies. Table 3 shows alternative application of microalgae in different fields.

The majority of microalgae species facilitate biodiesel production due to high content of lipids $(50-70 \%)$ and can reach up to $80 \%$ in the case of $B$. braunii [5].

Microalgae also produce different types of medically important polysaccharides. Different species can produce commercially important pigments such as chlorophyll, betacarotene, phycobiliproteins, carotenoids, astaxanthin. These pigments are necessary to fight against tumor formation, neurological pathologies and optical diseases. Microalgae are also rich in proteins. They produce important amino acids, which first of all increases their potential to enrich food with proteins. 


\section{Multilateral application of microalgae in industries [26]}

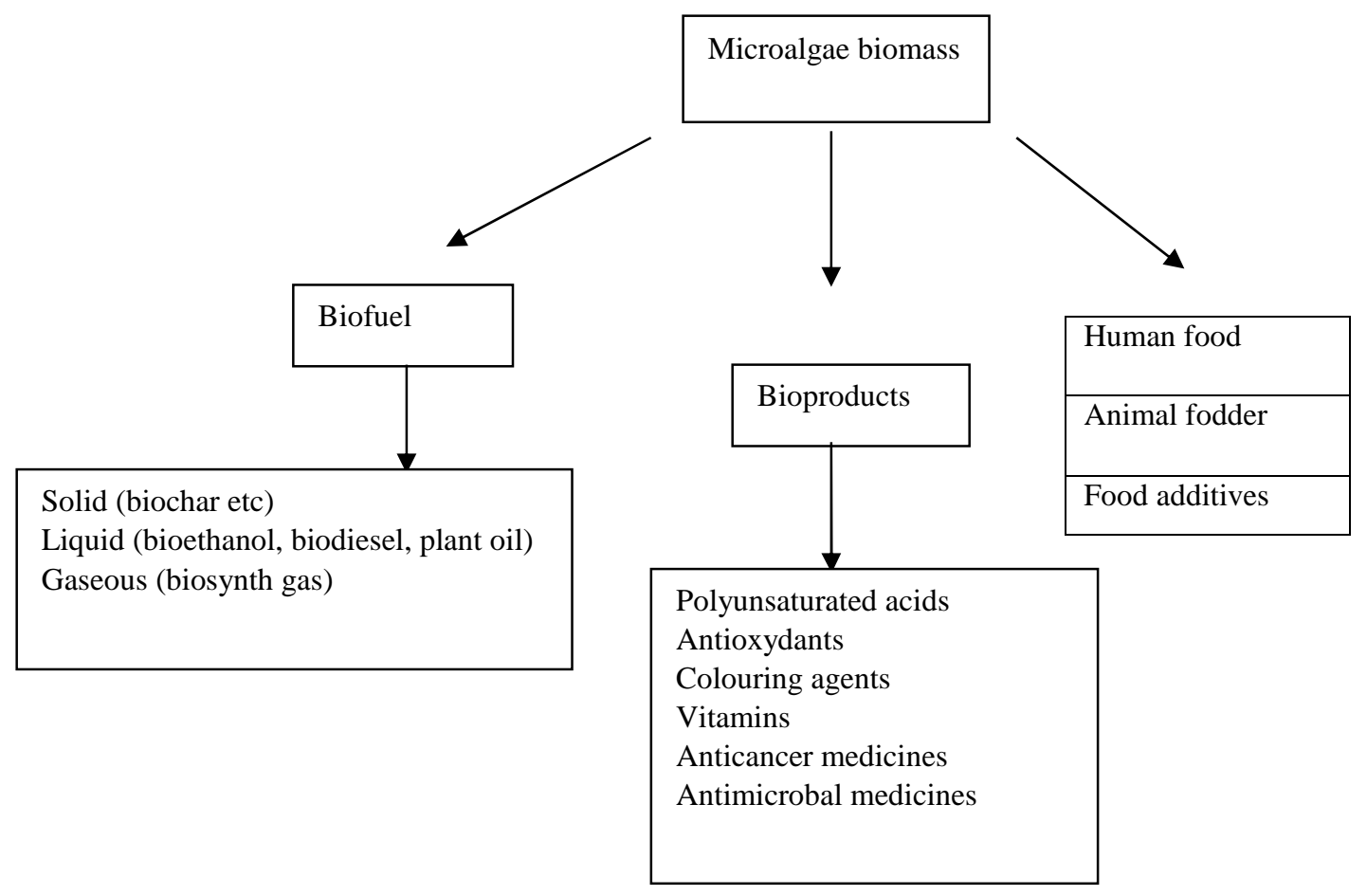

Microalgae also synthesize starch, cellulose, hemicellulose and other polysaccharides from simple monomeric sugars, particularly glucose. High content of carbohydrates in algae cells makes them an important source of food [11].

Cylindrotheca closterium and Phaeodactylum tricornutum are two microalgae species that produce fucoxanthin [60], which shows great potential in their application as anticancer, antidiabetic, antioxidant and anti-inflammatory agents [22].

$M$. aeruginosa is rich in several toxic metabolites that have cytotoxic and antimicrobial effect [26].

\section{Conclusion}

Macrophytes and microphytes play an important role in water ecosystem. There are many biotechnologies using different representatives of macrophytes and microphytes as raw material. More and more attention is being paid to the problem of sustainable environmental management with the use of these hydrobionts. Apart from perspectives, there are also problems connected with excessive accumulation of macrophytes and microphytes in water media. Nevertheless, when choosing a strategic approach to the solution of such problems, we besides elimination of the problem, get additional benefit for energy supply and development of other fields where macrophytes and microphytes can be used as raw material.

\section{References}

[1] Abdulrashid Muhammad Haidara, Ibrahim Muhammad Magami, Aminu Sanda. Bioremediation of Aquacultural Effluents Using Hydrophytes. Bioprocess Engineering. Vol. 2, No. 4, 2018, pp. 33-37. doi: 10.11648/ j.be.20180204.11

[2] Brogan W. R. III, Relyea R. A. A new mechanism of macrophyte mitigation: How submerged plants reduce malathion's acute toxicity to aquatic animals. Chemosphere 2014;108: 405-410. pmid: 24630450

[3] Brogan W. R. III, Relyea R. A. (2015) Submerged Macrophytes Mitigate Direct and Indirect Insecticide Effects in Freshwater Communities. PLoS ONE 10(5): e0126677. https://doi.org/10.1371/journal. pone. 0126677

[4] Characteristics of Hydrophytes with PPT (Classification and Adaptations). https://www.easybiologyclass.com/ characteristics-of-hydrophytes-with-ppt-classificationand-adaptations/. Last accessed 11.06.2019

[5] Chisti Y. Biodiesel from microalgae. Biotechnol Adv. 2007;25(3):294-306.

[6] CyanoHABs Newsletters 2018. https://www.epa.gov/ cyanohabs/cyanohabs-newsletters-2018. Last accessed 11.06.2019 
[7] Daneshian, M., A roadmap for hazard monitoring and risk assessment of marine biotoxins on the basis of chemical and biological test systems. Altex, 2013. 30(4): 487-545

[8] Eliška Rejmánková. The role of macrophytes in wetland ecosystems. J. Ecol. Field Biol. 34(4): 333-345, 2011. DOI: 10.5141/JEFB.2011.044

[9] Euglenoids. https://www.landcareresearch.co.nz/resources/ identification/algae/identification-guide/identify/guide/ descriptions/euglenoids. Last accessed 11.06.2019

[10] Freshwater Harmful Algal Blooms: Causes, Challenges, and Policy Considerations, 20.09.2018. Congressional Research Service. https://crsreports.congress.gov

[11] Guil-Guerrero J. L., Navarro-Juarez R., LopezMartinez J. C., Campra-Madrid P., Rebolloso-Fuentes M. M. Functionnal properties of the biomass of three microalgal species. J Food Eng. 2004;65:511-517

[12] Hilt S., Gross E. M. Can allelopathically active submerged macrophyte stabilize clear-water states in shallow lakes. Basic Appl Ecol 2008;9: 422-432

[13] Ho S. H., Chen C. Y., Chang J. S. Effect of light intensity and nitrogen starvation on $\mathrm{CO}_{2}$ fixation and lipid/carbohydrate production of an indigenous microalgae Scenedesmus obliquus CNW-N. Bioresour Technol. 2012;113:244-252

[14] Hydrophytes And Classification of Hydrophytes. https://www.brainkart.com/article/Hydrophytes-AndClassification-of-Hydrophytes_978/. Last accessed 11.06.2019

[15] Introduction to the Xanthophyta. https://ucmp. berkeley.edu/chromista/xanthophyta.html. Last accessed 11.06.2019

[16] J. L. Graham, N. M. Dubrovsky, and S. M. Eberts, Cyanobacterial Harmful Algal Blooms and U.S. Geological Survey Science Capabilities, U.S. Geological Survey Report 2016-1174, 2016, pp. 1-2

[17] Isabella Sanseverino, Diana Conduto, Luca Pozzoli, Srdan Dobricic and Teresa Lettieri. Algal bloom and its economic impact. JRC Technical Reports, 2016

[18] José Miguel Fariña; Andrés Camaño. The ecology and natural history of Chilean saltmarshes. Cham : Springer, 2017

[19] Juan Rocha et al. Freshwater Eutrophication. https://regimeshifts.org/item/55-freshwatereutrophication. Last accessed 11.06.2019

[20] L. Naselli-Flores, R. Barone. Green Algae. Encyclopedia of Inland Waters, 2009/

[21] Lefebvre, K. A. and A. Robertson, Domoic acid and human exposure risks: a review. Toxicon, 2010. 56(2): p. $218-30$

[22] Maeda H, Hosokawa M, Sashima T, Funayama K, Miyashita K. Effect of medium-chain triacylglycerols on anti-obesity effect of fucoxanthin. J Oleo Sci. 2007;56(12):615-621

[23] Main aquatic weed problems in Africa. http://www.fao. org/3/y4270e/y4270e03.htm. Last accessed 11.06.2019

[24] Michael F. Chislock et al. Eutrophication: Causes, Consequences, and Controls in Aquatic Ecosystems. https://www.nature.com/scitable/knowledge/library/ eutrophication-causes-consequences-and-controls-inaquatic-102364466. Last accessed 11.06.2019

[25] Monia Renzi et al. Biofuel Production from the Orbetello Lagoon Macrophytes: Efficiency of Lipid Extraction Using Accelerate Solvent Extraction Technique. Journal of Environmental Protection Vol.4 No.11(2013), Article ID:39246,6 pages

[26] Muhammad Imran Khan et al. The promising future of microalgae: current status, challenges, and optimization of a sustainable and renewable industry for biofuels, feed, and other products. Microb Cell Fact. 2018; 17: 36

[27] Plant Adaptations: Introduction and Ecological Classification of Plants. http://www.biologydiscussion. com/plants/plant-adaptations-introduction-and-ecologicalclassification-of-plants/6902. Last accessed 11.06.2019

[28] Said M. Badr El-Din, Reda A. Abdel-Aziz. Potential uses of aquatic plants for wastewater treatment. Microbiol Biotechnol Rep Vol 2 No 3 December 2018

[29] Sand-Jensen J., Borum J. Interactions among phytoplankton, periphyton, and macrophytes in temperature freshwaters and estuaries. Aquat Bot 1991;41: 137-175

[30] Slembrouck J., Samsudin R., Pantjara B., Sihabuddin A., Legendre M., Caruso D. 2018. Choosing floating macrophytes for ecological intensification of small-scale fish farming in tropical areas: a methodological approach. Aquat. Living Resour. 31: 30

[31] Stabenau, N., Zehnsdorf, A., Rönicke, H. et al. Energ Sustain Soc (2018) 8: 16 . https://doi.org/ 10.1186/s13705-018-0155-2

[32] Teygeler, R. (2000) Waterhyacintpapier. Bijdrage aan een duurzame toekomst /Water hyacinth paper. Contribution to a sustainable future [bi-lingual].. In (Torley and Gentenaar (eds.): Papier en Water/Paper and Water. Rijswijk, Gentenaar \& Torley Publishers, pp. $168-188$

[33] What Is Brown Algae? https://www.thoughtco. com/brown-algae-phaeophyta-2291972. Last accessed 11.06.2019

[34] Wetzel R. G. Limnology: Lake and River ecosystems. Third edition. Academic Press, New York, USA; 2001

[35] Yilmaz, Dilek \& Aksoy, Ahmet. (2006). Common hydrophytes as bioindicators of iron and manganese pollutions. Ecological Indicators - ECOL INDIC. 6. 10.1016/j.ecolind.2005.04.004 